\title{
Determinan Stres Kerja pada Penjaga Palang Pintu Rel Kereta Api Resmi Resort 9.6 Daerah Operasi IX di Kabupaten Jember
}

\author{
Dhanny Indra Prasetya ${ }^{1}$, Isa Ma'rufi ${ }^{1}$, Reny Indrayani ${ }^{1}$ \\ Fakultas Kesehatan Masyarakat, Universitas Jember, Indonesia \\ e-mail: dhannyindra.di@gmail.com
}

\begin{abstract}
Transportation sector development is one of the sub sectors that is important to support economic development. Poor transportation sector will develop human activities. One type of transportation is a train that has a special line and avoid congestion, Sometimes the train also cut off the highway, so the railway door is made to function to secure the train journey and guarded the door keepers. The problem in the concern at PT KAI is human error, One example of human error is a door keepers undisciplined in closing the railway door gates. One of the danger areas is Jember Regency which is located in DAOP IX, it is because Jember Regency had the most railway door in DAOP IX and has many crossings in the settlement area. The results of observations before the study found some workers who show symptoms of work stress. Jember regency had 12 official railway door and there are 47 door keepers who are all male. The door keepers are mostly 25-40 years old, have a working period of 1-5 years, have married marriage status, and have children $<3$, have wage I salary $R p$ 1,500,000-Rp 3,500,000, almost half of the respondents experienced fatigue and severe stress. The results of the study found there is a relationship between age, employment, marital status, wages / salary with work stress, but fatigue and wages/salary are not related to work stress.
\end{abstract}

Keywords: door keepers, human error, work stress.

\section{Pendahuluan}

Pembangunan sektor transportasi adalah salah satu subsektor yang penting untuk menunjang pembangunan ekonomi. Buruknya pembangunan sektor transportasi akan menghambat roda perekonomian masyarakat. Mobilitas masyarakat menjadi rendah, demikian pula pengangkutan barang dan jasa menjadi terhambat. Salah satu jenis transportasi tersebut adalah kereta api yang memiliki banyak keunggulan seperti dapat mengangkut penumpang secara masal dan tepat waktu karena memiliki jalur khusus yang terhindar dari kemacatan, terkadang jalur kereta api juga memotong jalan raya. Maka dibuatlah palang pintu rel kereta api yang fungsinya untuk mengamankan perjalanan kereta api (Republik Indonesia, 2007).

Kereta api memiliki reputasi yang baik dimata penumpang dibandingkan dengan transportasi darat yang lain, tetapi disamping hal tersebut ternyata ada beberapa kecelakaan yang sering terjadi. Menurut data dari Direktorat Jendral Perkeretaapian persentase penyebab kecelakaan kereta api didominasi oleh prasarana $41 \%$, human error $33 \%$ dan penyebab lainnya $26 \%$, dari ketiga faktor tersebut human error adalah penyebab yang paling banyak mendapat sorotan karena sebenarnya dapat dicegah sebelum terjadinya kecelakaan dan berbeda dibandingkan faktor penyebab yang lainnya (KNKT, 2016).
Beberapa contoh kecelakaan kereta api yang disebabkan oleh human error seperti yang terjadi di Pasuruan Bangil kecelakaan kereta mutiara timur yang menabrak 2 truk dan mobil box, lalu di Jember kecelakaan kereta probowangi yang menabrak mobil dan menyebabkan korban meninggal. Kecelakaan tersebut disebabkan oleh lalainya penjaga palang pintu untuk menutup palang pintu perlintasan [Data investigasi kecelakaan $\mathrm{KAI}$ ]

Melihat pentingnya fungsi dari penjaga palang pintu tersebut, PT KAI memiliki daerah operasi (DAOP) yang terbadi menjadi 9, salah satu DAOP tersebut adalah DAOP IX di Jember yang memiliki jalur mulai dari pasuruan hingga banyuwangi, dari DAOP IX tersebut Jember merupakan salah satu daerah yang rawan karena memiliki perlintasan terbanyak di DAOP IX dan banyak perlintasan yang melintas di area pemukiman warga sehingga sangat berbahaya (KNKT, 2016).

Berdasarkan observasi yang dilakukan kepada penjaga palang pintu di Kabupaten Jember, ditemukan beberapa temuan seperti terlambatnya beberapa penjaga palang pintu saat hendak dilakukan pengarahan sebelum pergantian shift, beberapa penjaga palang pintu yang menguap saat dilakukan pengarahan, lemas dan terlihat tidak bersemangat. Terlihat bahwa terdapat gangguan pada perilaku dan fisik penjaga palang pintu. Gangguan pada 
perilaku dan fisik saat bekerja merupakan gejala dari stres kerja (Sopiah, 2008).

Stres kerja adalah suatu keadaan dimana terjadi ketidakmampuan pekerja dalam menghadapi tuntutan tugas yang berakibat pada ketidaknyamanan ketika bekerja (Tarwaka, 2014). Stres dapat dialami dalam berbagai situasi keadaan manusia, seperti stres yang dialami dalam dunia kerja. Dunia kerja merupakan salah satu konteks yang erat hubungannya dengan stres. Stres yang dialami dalam dunia kerja sering disebut dengan stres kerja (occupational stres).

Faktor penyebab stres kerja bermacam-macam diantaranya karena faktor individu (umur, masa kerja, status pernikahan dan jumlah anak), faktor pekerjaan (upah/gaji) dan kelelahan kerja. Faktor lain yang juga dapat menyebabkan timbulnya stres seperti peran individu dalam lingkungan kerja, faktor hubungan antar pekerja, faktor pengembangan karir, faktor struktur organisasi, suasana kerja dan faktor dari luar pekerjaan (NIOSH, 1999).

Dampak dari stres kerja dapat berupa positif dan negatif (Tarwaka, 2013). Stres kerja yang memiliki pengaruh positif atau biasa disebut eustres, seperti motivasi pribadi, suatu rangsangan untuk bekerja lebih keras dan meningkatkan inspirasi hidup yang lebih baik, sedangkan stres yang berdampak negatif sebenarnya dapat merupakan fungsi dari pekerjaan itu, sebab kuantitas stres yang optimum akan didapati pada setiap orang dan tugas. Stres kerja juga bisa dihadapi oleh seorang penjaga pintu perlintasan kereta api, karena penjaga pintu perlintasan kereta api juga memiliki keterbatasan yang dapat menyebabkan kondisi tersebut. Perasaan seperti rasa kantuk, rasa lelah, namun di sisi lain mereka dituntut harus siap dan berada dalam kondisi yang prima ketika jadwal tugas untuknya tiba, karena sebentar saja mereka lengah, nyawa manusia yang menjadi korbannya

Berdasarkan hal tersebut peneliti tertarik untuk melakukan penelitian dan menemukan apakah determinan yang dapat menyebabkan stres kerja pada penjaga palang pintu rel kerea api di resort 9.6 Kabupaten Jember

\section{Metode Penelitian}

Penelitian ini merupakan penelitian analitic observasional yaitu penelitian tanpa melakukan intervesi kepada objek atau noneksperiman.

\subsection{Metode Pengumpulan Data}

Populasi penelitian ini sebanyak 47 penjaga palang pintu rel kereta api resort 9.6 DAOP IX Kabupaten Jember dan pemilihan sampel menggunakan rumus Lameshow et al (1990) dengan taraf kesalahan 5\%, sehingga menghasilkan sampel sejumlah 42 penjaga palang pintu. pengambilan sampel menggunakan metode simple random sampling.

Variabel-variabel yang terkait dengan penelitian ini terbagi menjadi 2 yaitu dependen (terikat) dan independen (bebas), yang menjadi variabel dependen (terikat) adalah stres kerja sedangkan untuk variabel independen (bebas) adalah determinan stres kerja yang terdiri dari karakteristik individu (umur, masa kerja, status pernikahan, jumlah anak), status pekerjaan (upah/gaji) dan kelelahan kerja.

\subsection{Metode Analisis Data}

Semua data dikumpulkan dengan teknik wawancara menggunakan panduan wawancara dan instrumen kuesioner dari OSI$\mathrm{R}^{\mathrm{TM}}$ (Occupational Stres Inventory - Revisied Edition) serta SSRT (Subjective Self Rating Test). Selanjutnya, analisis data menggunakan analisis univariat, analisis bivariat dengan uji chi-square dan uji spearman.

\section{Hasil dan Pembahasan}

Semua responden yang telah dipilih menjadi sampel sejumlah 42 penjaga palang pintu diwawancarai saat bekerja sebagai penjaga palang pintu.

\section{a. Karakteristik Responden}

Karakteristik responden adalah ciri yang dimiliki responden sebagai sebagian dri identitas, data tersebut diambil selama 31 hari pada tanggal 4 April - 4 Mei 2018. Tabel 1 menunjukkan karakteristik responden yang meliputi umur, masa kerja, status pernikahan, dan jumlah anak.

\section{b. Upah/gaji}

Upah/gaji adalah pendapatan maksimal berupa uang yang diperoleh penjaga palang pintu rel kereta api setiap bulan. Distribusi frekuensi berdasarkan tingkat pendapatan dapat dilihat pada tabel 2 . 
Tabel 1. Karakteristik Responden

\begin{tabular}{lll}
\hline \multicolumn{1}{c}{ Karakteristik Individu } & Jumlah (n) & $\begin{array}{c}\text { Persentase } \\
(\%)\end{array}$ \\
\hline Umur & & \\
$\leq 24$ tahun & 5 & 11,9 \\
$25-40$ tahun & 27 & 64,3 \\
$41-65$ tahun & 10 & 23,8 \\
$>65$ tahun & 0 & 0 \\
$\leq 24$ tahun & 5 & 11,9 \\
Jumlah & 42 & 100 \\
& & \\
Masa Kerja & & \\
$1-5$ tahun & 24 & 57,1 \\
$6-10$ tahun & 9 & 21,4 \\
$\geq 10$ tahun & 9 & 21,4 \\
Jumlah & 42 & 100 \\
& & \\
Status Pernikahan & & \\
Tidak menikah & 10 & 23,8 \\
Sudah menikah & 32 & 76,2 \\
Jumlah & 42 & 100 \\
& & \\
Jumlah anak & & 92,9 \\
$\leq 3$ & 39 & 7,1 \\
$>3$ & 3 & 100 \\
Jumlah & 42 &
\end{tabular}

Tabel 2. Distribusi Frekuensi tingkat pendapatan.

\begin{tabular}{lcc}
\hline $\begin{array}{c}\text { Tingkat } \\
\text { Pendapatan }\end{array}$ & Frekuensi & Persentase (\%) \\
\hline$<$ Rp 1.500 .000 & 0 & 0 \\
Rp. $1.500 .000-$ & 26 & 61,9 \\
Rp. 3.500 .000 & & 38,1 \\
$>$ Rp. 3.500.000 & 17 & 100 \\
\hline Jumlah & 42 & \\
\hline
\end{tabular}

\section{c. Kelelahan Kerja}

Kelelahan kerja adalah perasaan yang dirasakan oleh pekerja meliputi 3 kategori yaitu pelemahan kegiatan, pelemahan motivasi dan pelemahan fisik yang dialami oleh responden ketika berjaga di pos. Distribusi frekuensi berdasarkan kelelahan kerja yang dialami responden dapat dilihat pada tabel 3 .

Tabel 3. Distribusi frekuensi tingkat kelelahan kerja.

\begin{tabular}{lcc}
\hline \multicolumn{1}{c}{$\begin{array}{c}\text { Tingkat } \\
\text { Kelelahan } \\
\text { Kerja }\end{array}$} & Frekuensi & Persentase (\%) \\
\hline $\begin{array}{l}\text { Kelelahan } \\
\text { ringan }\end{array}$ & 19 & 45,2 \\
Kelelahan berat & 23 & 54,8 \\
\hline Jumlah & 42 & 100 \\
\hline
\end{tabular}

\section{d. Stres Kerja}

Stres kerja adalah tekanan, ketegangan atau gangguan yang dialami responden ketika bekerja yang menyebabkan ketidaknyamanan dalam bekerja. Distribusi frekuensi berdasarkan tungkat stres yang dialami responden dapat dilihat pada tabel 4 .

Tabel 4. Distribusi frekuensi tingkat stress kerja.

\begin{tabular}{lll}
\hline $\begin{array}{c}\text { Tingkat Stres } \\
\text { Kerja }\end{array}$ & Frekuensi & Persentase (\%) \\
\hline Stres ringan & 6 & 14,3 \\
Stres sedang & 13 & 31 \\
Stres berat & 23 & 54,8 \\
\hline Total & 42 & 100 \\
\hline
\end{tabular}

\section{e. Hubungaan karakteristik individu dengan stres kerja}

1) Hubungan umur dengan stres kerja

Hasil analisis menggunakan uji spearman didapatkan p-value 0,000 atau $<\alpha$ 0,05 , maka dapat dikatakan kedua variabel berhubungan. Kekuatan korelasi ditunjukkan dengan hasil (r) sebesar 0,580 yang berarti memiliki tingkat hubungan yang sedang. Arah hubungan pada tabel menunjukkan negatif atau tidak searah yang artinya semakin tua responden, maka tingkat stres kerja yang dialami responden akan rendah.

\section{2) Hubungan masa kerja dengan stres kerja}

Hasil analisis menggunakan uji spearman didapatkan p-value 0,001 atau $<\alpha$ 0,05 , maka dapat dikatakan kedua variabel berhubungan. Kekuatan korelasi ditunjukkan dengan hasil (r) sebesar 0,480 yang berarti memiliki tingkat hubungan yang sedang. Arah hubungan pada tabel menunjukkan negatif atau tidak searah yang artinya semakin banyak masa kerja responden, maka tingkat stres kerja yang dialami responden akan rendah.

\section{3) Hubungan status pernikahan dengan stres kerja \\ Hasil analisis menunjukkan bahwa} hubungan antara status pernikahan dengan tingkat stres kerja memiliki nilai expected kurang dari 5 sebesar 50\% (>20\%),oleh karena itu perlu dilakukan penggabungan kategori untuk melanjutkan uji Chi Square, kategori yang digabungkan adalah stres kerja dari tiga kategori tingkatan stres menjadi dua kategori tingkatan stres. Hasil pada tabel 4.10 menunjukkan bahwa hubungan antara status pernikahan dengan stres kerja meniliki nilaiexpectedkurang dari 5 sebesar $25 \%$ (> $20 \%$ ), karena tabel tersebut berjenis $2 \times 2$ maka 
untuk mengetahui tingkat hubungan antara status pernikahan dengan stres kerja menggunakan Fisher's Exact Test. Hasil tersebut menunjukkan $p$-value $<\alpha 0,05$ yaitu 0,013 , sehingga dapat disimpulkan bahwa status pernikahan memiliki hubungan dengan tingkat stres kerja.

\section{4) Hubungan jumlah anak dengan stres kerja}

Hasil analisis menggunakan uji spearman didapatkan p-value 0,122 atau $>\alpha$ 0,05 , maka dapat dikatakan kedua variabel tidak berhubungan. Kekuatan korelasi ditunjukkan dengan hasil (r) sebesar 0,242 yang berarti memiliki tingkat hubungan yang lemah dengan arah hubungan positif.

\section{5) Hubungan Upah/Gaji Dengan Stres Kerja}

Hasil analisis menggunakan uji spearman didapatkan p-value 0,012 atau $<\alpha$ 0,05, maka dapat dikatakan kedua variabel signifikan atau berhubungan. Kekuatan korelasi ditunjukkan dengan hasil (r) sebesar 0,384 yang berarti memiliki tingkat hubungan yang lemah. Arah hubungan pada tabel menunjukkan negatif atau tidak searah yang artinya semakin besar upah atau gaji yang diterima, maka tingkat stres kerja yang dialami akan semakin rendah.

\section{6) Hubungan Kelelahan Kerja Dengan Stres Kerja \\ Hasil analisis menggunakan uji} spearman didapatkan $p$-value 0,803 atau $>\alpha$ 0,05 maka dapat dikatakan kedua variabel tidak berhubungan. Kekuatan korelasi ditunjukkan dengan hasil (r) sebesar 0,040 yang berarti memiliki tingkat hubungan yang sangat lemah dengan arah hubungan negatif.

Sebagian besar penjaga palang pintu berada pada rentang umur 25-40 tahun. Umur terendah dari penjaga palang pintu adalah $<24$ tahun. Umur berkaitan dengan kapasitas fisik seseorang sehingga semakin tua umur seseorang maka akan disertai penurunan dalam mengatasi kurangnya kemampuan kerja oleh karena perubahan pada alat tubuh, sistem kardiovaskuler dan hormonal (Suma'mur, 2014).

Sebagian besar masa kerja yang dimiliki oleh penjaga palang pintu 1-5 tahun sebanyak 24 responden. Masa kerja yang lebih banyak berada pada rentang 1-5 tahun ini dikarenakan sebagian responden baru bekerja menjadi penjaga palang pintu setelah lulus dari bangku sekolah SMA, beberapa juga ada penjaga palang pintu yang memiliki masa kerja di rentang 1-5 tahun merupakan pekerja pindahan dari sarana (pengecekkan jalan jembatan) ke penjaga perlintasan.

Sebagian besar status pernikahan yang dimilki oleh penjaga palang pintu adalah sudah menikah dengan 32 responden $(76,2 \%)$. Sudah menikah memilki rentang angka tertinggi dapat disebabkan oleh usia yang sudah memasuki usia matang untuk menikah dan berdasarkan wawancara sebagian besar responden yang sudah bekerja dengan masa kerja lebih dari 3 tahun merasa cukup dengan penghasilan sebagai pekerja PT.Kereta Api Indonesia dan merasa cukup mapan.

Sebagian besar para penjaga palang pintu memilki anak $\leq 3$ sebanyak 39 responden $(92,9 \%)$ dan $>3$ sebanyak 3 responden $(7,1 \%)$. Kehadiran anak dalam sebuah pernikahan dianggap sebagai penyatu hubungan antara suami dan istri,akan tetapi di lain pihak kehadiran anak dalam sebuah pernikahan dapat mengakibatkan menurunnya kepuasan pernikahan. Menurunnya kepuasan pernikahan ini sebagai dampak adanya transisi menjadi pasangan orang tua sehingga dapat menimbulkan perasaan stres. Hal ini seringkali terjadi setelah kelahiran anak pertama (Shute, 2009).

Sebagian besar para penjaga palang pintu memiliki upah/gaji antara Rp.1.500.000 - Rp.3.500.000 sebanyak 26 responden (26\%). Upah/gaji di penjaga palang pintu PT Kereta Api Indonesia dibedakan menjadi 2 yaitu organik dan pihak ketiga/vendor. Organik sendiri umumnya memiliki upah/gaji diatas Rp.4.000.000 karena banyak tunjangan yang didapatkan dari perusahaan, sedangkan untuk pihak ketiga/vendor yang diluar perusahaan umumnya memiliki upah/gaji UMR ditambah dengan tunjangan kerja, jika ditotal sekitar Rp.2.140.000. Kelompok upah/gaji Rp.1.500.000 - Rp.3.500.000 masuk dalam kelompok pendapatan sedang (Badan Pusat Statistik, 2014). Pemberian gaji hendaknya benar-benar diperhatikan oleh perusahaan karena pemberian gaji yang pantas akan berdampak positif bagi karyawan (Mangkunegara, 2013).

Sebagian besar para penjaga palang pintu mengalami kelelahan berat sebanyak 23 responden $(54,8 \%)$. Kelelahan kerja sangat 
mungkin terjadi melihat kerja dari penjaga palang pintu yang statis dan diharuskan selalu siap ketika ada kereta lewat dan mengamankan area operasinya. pembagian waktu kerja juga sangat berpengaruh terhadap tingkat kelelahan pekerja, ketika pekerja tidak dapat memanfaatkan waktu istirahatnya dengan baik sudah dapat dipastikan kelelahan akan terjadi saat mereka berjaga (Hariyati, 2011). Kelelahan menunjukkan kondisi yang berbedabeda dari setiap individu, tetapi semuanya bermuara kepada kehilangan efisiensi dan penurunan kapasitas kerja serta ketahanan tubuh. Kelelahan sangat berbahaya tentunya jika terjadi saat penjaga palang pintu sedang bekerja, apabila setiap individu tidak memiliki manajemen diri yang baik (Hariyati, 2011).

Umur berhubungan dengan tingkat kedewasaan, secara tehnis maupun psikologis semakin bertambah umur seseorang maka akan meningkat kedewasaannya, kematangan jiwanya dan kemampuan dalam menjalankan tugasnya. Semakin bertambah umur akan membuat seseorang memilki kemampuan membuat keputusan lebih baik, semakin bijaksana, berfikir rasional dan mudah mengendalikan emosinya, lebih toleran dan terbuka dengan pandangan orang lain. Pekerja yang lebih tua dan yang berpengalaman memiliki stres kerja yang ringan (Mangkunegara, 2013).

Hasil tersebut bertentangan dengan penelitian yang menghasilkan tidak terdapatnya hubungan antara umur dengan stres yang diakibatkan perusahaan membedakan jenis pekerjaan yang diberikan kepada pekerja, sehingga masa kerja dan beban yang di dapat antar pekerja berbeda (Yudha, 2010).

Hasil penelitian ini sesuai dengan teori yang ada, dengan jenis pekerjaan dan beban kerja yang sama. Yaitu jika semakin tua seseorang maka semakin berkurang juga tingkat stres yang dialami. Sesuai dengan arah uji spearman menunjukkan negatif yang berarti semakin tua seseorang akan memiliki tingkat stres semakin berkurang. Mayoritas penjaga palang pintu berumur 25-40 yang masuk dalam kategori menuju umur tua, sehingga para pekerja di penjaga palang pintu memiliki stres yang rendah

Hasil penelitian ini menunjukkan bahwa masa kerja mempunyai hubungan dengan tingkat stres penjaga palang pintu, penjaga palang pintu dengan masa kerja sedikit mempunyai kecenderungan untuk mengalami stres. Hal ini dapat disebabkan karena belum terbiasa penjaga palang pintu dengan budaya kerja PT KAI dan lingkungan tempat kerja sehingga masih butuh waktu untuk menyesuaikan dengan situsi yang ada.Pengaruh lingkungan cukup kuat, seperti penelitian yang menghasilkan bahwa lingkungan kerja berpengaruh terhadap kinerja dan stres pekerja. Penelitian tersebut menghasilkan lingkungan kerja berpengaruh positif terhadap tingkat kinerja dan stres pekerja (Melindasari, 2015)[13]

Pekerja yang berstatus sudah menikah lebih cenderung mengalami tingkat stres rendah dari pada yang belum menikah. Hal tersebut berhubungan dengan dukungan emosional dari pasangan yang tidak didapatkan dari pekerja yang belum menikah (Olatunji and Mokuolu, 2014).

Hasil ini bertentangan dengan penelitian yang mencantumkan tentang faktorfaktor yang berhubungan dengan stres kerja pada pekerja di perusahaan. Hal tersebut disebabkan rata-rata pekerja yang mengalami stres pada yang sudah menikah maupun tidak menikah dikarenakan faktor jam pekerjaan yang sama tingginya, hal tersebut membuat keduanya memiliki tingkat stres yang serupa dan memilki hubungan pernikahan yang tidak baik dengan pasangannya.

Hasil penelitian ini menunjukkan jika lebih banyak pekerja yang sudah menikah daripada yang tidak menikah. Pada tabel distribusi frekuensi status pernikahan responden terlihat jika tingkat stres yang dialami responden pada kelompok responden menikah terbanyak berada pada tingkat stres sedang, sedangkan pada tidak menikah terbanyak berada pada tingkat stres berat. Melihat hasil tersebut dapat dikatakan jika penelitian ini sesuai dengan teori yang ada, yang berarti responden dengan status pernikahan menikah memiliki tingkat stres lebih sedikit daripada yang tidak menikah

Jumlah anak pada penelitian ini tidak berhubungan dengan Stres Kerja yang dialami penjaga palang pintu, karena mayoritas responden memiliki umur $<3$, jika dijabarkan kembali dari $<3$ tersebut mayoritas pekerja tidak memiliki anak sebanyak 10 responden dan memiliki anak 1 sebanyak 29 responden, sehingga ketika tidak ada hubungan antara jumlah anak dengan stres kerja pada penelitian ini dapat diakibatkan oleh mayoritas 
responden memiliki anak yang sedikit yaitu 1 orang dan apabila dilakukan uji analisis tidak ada hubungan karena banyak sell yang tidak terisi.

Penjaga palang pintu rel kereta api memilki upah/gaji yang sama dengan beban pekerjaan dan jumlah jam kerja yang sama baik pegawai organik maupun non organik/vendor, yang membedakan hanya tunjangan yang diterima. Pekerja dengan status organik memilki upah/gaji lebih besar daripada pekerja pihak non organik/vendor, hal tersebut disebabkan pekerja organik berada di bawah naungan PT. KAI sedangkan pihak ketiga/vendor di bawah naungan penyedia jasa pekerjaan. Pada umumnya gaji yang diterima oleh penjaga palang pintu rel kereta api di atas UMR Kabupaten Jember dan dapat dikatakan cukup. Kelompok upah/gaji Rp.1.500.000 Rp.3.500.000 masuk dalam kelompok pendapatan sedang (Badan Pusat Statistik, 2014).

Pemberian gaji hendaknya benarbenar diperhatikan oleh perusahaan karena pemberian gaji yang pantas akan berdampak positif bagi karyawan, sebab gaji adalah untuk memenuhi berbagai kebutuhan karyawan (Tarwaka, 2014). Pemberian gaji berhubungan dengan tingkat stres yang dialami oleh penjaga palang pintu rel kereta api, terbukti dari arah penelitian menunjukkan arah negatif yang berarti semakin besar upah/ gaji yang diterima, maka tingkat stres kerja yang dialami akan berkurang maupun sebaliknya.

Kelelahan kerja tidak berhubungan dengan stres kerja, hal tersebut disebabkan oleh manajemen organisasi yang baik dan lingkungan yang nyaman. Selain membuka dan menutup palang pintu ketika ada kereta yang lewat, penjaga palang pintu juga diberi tugas untuk membersihkan lingkungan disekitar jalur perlintasan, menata taman yang ada dan menciptakan lingkungan yang nyaman di tempat kerja, hal tersebut dapat menjadi penyebab mengapa tingginya tingkat kelelahan kerja yang dialami oleh pekerja karena hampir setengah dari responden mengalami kelelahan berat. Walaupun mengalami kelelahan berat, pada uji statistik tidak ditemukan adanya hubungan dengan stres kerja, hal tersebut juga dapat disebabkan hampir semua penjaga palang pintu memiliki hubungan yang baik dengan lingkungan kerjanya, dalam hal ini lingkungan kerjanya adalah warga disekitar jalur perlintasan. Hal tersebut dapat dibuktikan dari adanya warga yang membantu ketika palang pintu otomatis tidak mau beroperasi sehingga harus diangkat dengan manual dan selalu adanya warga yang mengunjungi pos perlintasan untuk sekedar bergurau atau menemani penjaga perlintasan

\section{Simpulan dan Saran 4.1 Simpulan}

Hasil penelitian menunjukkan bahwa pekerja sebagian besar responden berumur 2540 tahun, memiliki masa kerja 1-5 tahun, memiliki status pernikahan sudah menikah, memiliki jumlah anak $\leq 3$ dan upah/gaji Rp.1.500.000-Rp.3.500.000, lebih dari setengah sampel mengalami kelelahan berat, lebih dari setengah sampel mengalami stres berat, Berdasarkan hasil uji statistik menggunakan Spearman dan Chi Square faktor yang berhubungan dengan stres kerja pada penjaga palang pintu rel kereta api resort 9.6 Kabupaten Jember adalah dari umur, masa kerja, status pernikahan dan upah/gaji dengan $p$ value $<0,05$ dan memiliki arah negatif yang artinya semakin besar atau banyak nilai dari variabel tersebut akan menghasilkan tingkat stres yang lebih rendah. Faktor yang tidak berhubungan adalah jumlah anak ( $p$ value $=0,122)$ dan kelelahan kerja $(p$ value $=0,803$ ).

\subsection{Simpulan}

Saran yang diberikan berdasarkan hasil penelitian ini adalah bagi perusahaan meningkatkan intensitas kunjungan ke tiap JPL, melakukan pengukuran stres kerja secara berkala kepada penjaga palang pintu, memperhatikan kesejahteraan upah/gaji yang diterima oleh penjaga palang pintu rel kereta api. Bagi pekerja mengatur jam istirahat dengan baik dan lebih terbuka kepada atasan. Bagi peneliti selanjutnya meneliti faktor-faktor lain seperti tingkat kesejahteraan, faktor fisik dan faktor lingkungan yang dapat mempengaruhi stres pada penjaga palang pintu rel kereta api, memkombinasikan antara alat ukur subjektif dengan objektif ketika melakukan pengukuran, memperluas cakupan JPL yang diteliti.

\section{Daftar Pustaka}

Badan Pusat Statistik (2014) Penggolongan Tingkatan Gaji. Available at: http://jateng.bps.go.id/webbeta/frontend/ linkTabelStatis/view/id/655. 
Hariyati, M. (2011) Pengaruh Beban Kerja terhadap Kelelahan Kerja pada Pekerja Linting Manual Dipt. Djitoe Indonesia Tobacco Surakarta. Skripsi. Universitas Sebelas Maret.

KNKT (2016) Data Investigasi Kecelakaan Perkeretapian Tahun 2010-2016. Available at: http://knkt.dephub.go.id/knkt/ntsc_home

Mangkunegara, A. (2013) Manajemen Sumber Daya Manusia Perusahaan. Bandung: PT. Remaja Rosda Karya.

Melindasari, I. (2015) Pengaruh Lingkungan Kerja dan Stres Kerja Terhadap Kinerja Karyawan PT. Federal International Finance (FIF) Gresik. Skripsi. Universitas Wijaya Putra Surabaya.

NIOSH (1999) Stress At Work. What Can Be Done About Job Stress? Available at: http://www.cdc.gov/niosh/docs/99-

101/pdfs/99-101.pdf.

Olatunji and Mokuolu, B. (2014) 'The Influence of Sex, Marital Status, and Tneure of Service on Job Stress, and Job Satisfaction of Health Workers in a Nigerian 191 Federal Health Institution', Jurnal Internasional, 8(1), pp. 126-133.

Republik Indonesia (2007) Undang-Undang Republik Indonesia Nomor 23 tahun 2007 tentang Perkeretaapian.

Shute, N. (2009) Having Children Adds Stress to Marriage. Available at: http://health.usnews.com/healthnews/bl ogs/onparenting/2009/04/13/havingchild ren-adds-stress-to-marriage.

Sopiah (2008) Perilaku Organisasional. Yogyakarta: Andi Offset.

Suma'mur (2014) Higiene Perusahaan dan Kesehatan Kerja (HIPERKES). Jakarta: CV Sagung Seto.

Tarwaka (2013) Ergonomi Industri DasarDasar Pengetahuan Ergonomi dan Aplikasi di Tempat Kerja. Surakarta: Harapan Press Solo. dasar Pengetahuan Ergonomi dan Aplikasi di Tempat Kerja. Surakarta: Harapan Press Solo.

Yudha, F. (2010) Faktor yang Berhubungan dengan Kejadian Stres Kerja pada Bagian Produksi Industri Mebeul PT. Chia Jiann Indonesia Furniture di Wedelan Jepara Tahun 2009. Skripsi. Universitas Negeri Semarang.

Tarwaka (2014) Ergonomi Industri - Dasar- 